\title{
Гібридні методики в лікуванні патології грудної аорти
}

\author{
Мазур О. А., Дітківський І. О., Черпак Б. В., Кравченко В.І І. \\ ДУ «Національний інститут серцево-судинної хірургії імені М. М. Амосова НАМН» (Київ)
}

\begin{abstract}
Гібридний метод лікування патології грудної аорти позбавлений недоліків традиційних «відкритих» хірургічних методів лікування і водночас має ширші можливості застосування, ніж ендоваскулярний метод, 3 огляду на суттєві анатомічні обмеження останнього.

32014 по 2017 роки в ДУ «Національний інститут серцево-судинної хірургії імені М. М. Амосова НАМН» 41 пацієнт з патологією грудної аорти був пролікований гібридним методом (відкрита операція на судинах дуги аорти та ендопротезування низхідної аорти стент-графтом). $(\mathrm{n}=19)$ хворих мали аневризму низхідної аорти без розшарування або розриву; $(\mathrm{n}=19)$ хворих мали розшаровуючу аневризму аорти $(\mathrm{n}=4$ - гостру, $\mathrm{n}=2$ - підгостру, $\mathrm{n}=13$ - хронічну), двоє хворих мали розрив аорти без розшарування, і в одному випадку спостерігалася пенетруюча виразка аорти.

Пацієнтам, що поступали у плановому порядку або не мали загрозливих для життя станів, проводилося переключення судин дуги аорти (debranching) на першому етапі та ендопротезування низхідної аорти на другому етапі. Якщо існувала безпосередня загроза для життя пацієнта (розрив аорти, мальперфузія внутрішніх органів), спочатку проводилось ендопротезування аорти стент-графтом, а після стабілізації стану пацієнта виконувався відкритий етап лікування.

Контроль стану пацієнтів у віддаленому періоді проводився через три та шість місяців після гібридного лікування. Летальність склала 2,4\%, що значно менше цього показника при відкритому хірургічному протезуванні низхідної аорти. Серед ускладнень були endoleak I типу у віддаленому періоді; тромбоз каротидно-підключичного анастомозу, розшарування лівої підключичної артерії та травма зворотного гортанного нерва (по одному випадку). Віддалені результати лікування через три та шість місяців добрі.
\end{abstract}

Ключові слова: аневризма аорти, розшарування аорти, гібридне лікування, ендоваскулярне протезування грудної аорти, TEVAR, дебранчинг, каротидно-підключичне шунтування.

Ендоваскулярне протезування грудної аорти (TEVAR - Thoracic endovascular aortic repair) - метод, винайдений і вперше застосований нашим співвітчизником, професором М. Л. Володосем ще у 1987 році [1, 2]. Попри широкий спектр показань до ендопротезування грудної аорти (аневризми грудної аорти, розшарування аорти III типу за ДеБейкі, травматичний розрив аорти, пенетруюча виразка аорти), цей метод все ж має свої обмеження. Основним протипоказанням $є$ несприятливі анатомічні особливості. Зокрема, для успішної імплантації стент-графта необхідна неушкоджена зона стінки аорти довжиною близько 20 мм в обидва боки від місця ураження та відсутність у цій зоні вічок судин $[3,4]$. Саме тому гібридний метод лікування (TEVAR) у поєднанні $з$ хірургічним переключенням судин дуги аорти (debranching) має ширші показання до застосування. Гібридне лікування патології грудної аорти є методом вибору у випадку, коли в патологічний процес залучена дуга аорти або зона ураження знаходиться ближче, ніж 20 мм, від вічок судин дуги $[5,6]$. Під час хірургічного етапу судини дуги аорти реімплантуються у висхідну аорту проксимальніше їх природного розташування, у такий спосіб створюється вільна від вічок судин зона, необхідна для фіксації проксимального кінця стент-графта.

Метою роботи $є$ демонстрація власного досвіду і дослідження результатів гібридного лікування патології грудної аорти.

Матеріали та методи. 32014 по 2017 рік в ДУ «Національний інститут серцево-судинної хірургії імені М. М. Амосова НАMН» (HICCX) 41 хворий із патологією аорти переніс гібридне лікування: переключення гілок дуги аорти (debranching) та ендоваскулярне протезування низхідної аорти стент-графтом (TEVAR). У групі переважали чоловіки $(\mathrm{n}=34)$. Вік хворих становив від 23 до 79 років.

Структура пацієнтів за діагнозами наведена в табл. 1. Близько половини хворих $(\mathrm{n}=19)$ мали аневризму грудної аорти без розшарування або розриву. За етіологією найчастіше зустрічалися посткоарктаційні та посттравматичні аневризми аорти (відповідно $\mathrm{n}=7$; $\mathrm{n}=5$ ).

Така ж кількість хворих $(\mathrm{n}=19)$ мали розшаровуючу аневризму аорти. У чотирьох випадках спостерігалося хронічне розшарування аорти типу А за Стенфордською класифікацією. Трьом пацієнтам раніше виконувалося протезування висхідної аорти (в одному ви- 
Таблиця 1

Структура хворих за діагнозами

\begin{tabular}{|c|c|c|}
\hline Діагноз & $\begin{array}{c}\text { Кількість } \\
\text { хворих }\end{array}$ & $\begin{array}{c}\text { \% xво- } \\
\text { рих }\end{array}$ \\
\hline $\begin{array}{l}\text { Аневризма грудної аорти (ТАA, thoracic } \\
\text { aortic aneurysm) }\end{array}$ & 19 & $46,3 \%$ \\
\hline $\begin{array}{l}\text { - ут. ч. посттравматична аневризма } \\
\text { низхідної аорти }\end{array}$ & 5 & $12,2 \%$ \\
\hline $\begin{array}{l}\text { - у т. ч. посткоарктаційна аневризма } \\
\text { низхідної аорти }\end{array}$ & 7 & $17,1 \%$ \\
\hline $\begin{array}{l}\text { - ут. ч. аневризма грудної аорти } \\
\text { невизначеної етіології }\end{array}$ & 7 & $17,1 \%$ \\
\hline Розшаровуюча аневризма аорти & 19 & $46,3 \%$ \\
\hline - ут. Ч. гостра & 4 & $9,8 \%$ \\
\hline - у т. ч. підгостра & 2 & $4,9 \%$ \\
\hline - ут. ч. хронічна & 13 & $31,7 \%$ \\
\hline Пенетруюча виразка аорти & 1 & $2,4 \%$ \\
\hline Розрив аорти & 2 & $4,9 \%$ \\
\hline Усboro & 41 & $100,0 \%$ \\
\hline
\end{tabular}

падку - операція Bentall de Вono за 19 років до поточної госпіталізації; у двох випадках - супракоронарне протезування висхідної аорти за рік і за 4 роки до поточної госпіталізації); четвертий пацієнт до госпіталізації в HICCX не проходив хірургічного лікування. У решти пацієнтів спостерігалося розшарування аорти типу В (n=9 - хронічне; $\mathrm{n}=2-$ підгостре; $\mathrm{n}=4$ - гостре). У двох пацієнтів розшарування аорти було ускладнене лівобічним гемотораксом; у трьох - мальперфузією вісцеральних органів; в одного - гемотораксом і мальперфузією вісцеральних органів. Також у двох пацієнтів спостерігався розрив аорти без розшарування, що супроводжувався лівобічним гемотораксом; в одного пацієнта була виявлена пенетруюча виразка аорти.

Пацієнтам, що поступили на лікування в плановому порядку або не мали загрозливих для життя станів, на першому етапі виконувалося переключення гілок дуги аорти, після чого проводилось ендоваскулярне протезування низхідної аорти. Пацієнтам із загрозливими для життя станами (мальперфузія вісцеральних органів, розрив аорти з гемотораксом) першим етапом проводилася процедура TEVAR, а вже після стабілізації стану пацієнта виконувалося переключення судин дуги аорти. Також при наявності гемотораксу пацієнтам проводилось одномоментне дренування плевральної порожнини на операційному столі після імплантації стент-графта. За потребою, залежно від анатомічних особливостей та наявності endoleak з лівої підключичної артерії, також проводилося закриття лівої підключичної артерії оклюдером.

У табл. 2 наведена структура відкритих операцій, що проводилися хворим. Переключення судин дуги
Таблиця 2

Відкриті операції

\begin{tabular}{lcc} 
Операція & $\begin{array}{c}\text { Кількість } \\
\text { хворих }\end{array}$ & $\begin{array}{c}\text { \% хво- } \\
\text { рих }\end{array}$ \\
\hline Частковий debranching & $\mathbf{2 9}$ & $\mathbf{7 0 , 7 \%}$ \\
\hline Субтотальний debranching & $\mathbf{7}$ & $\mathbf{1 7 , 1 \%}$ \\
\hline Повний debranching & $\mathbf{5}$ & $\mathbf{1 2 , 2 \%}$ \\
\hline $\begin{array}{l}\text { - у т. ч. повний debranching та супрако- } \\
\text { ронарне протезування висхідної аорти }\end{array}$ & 2 & $4,9 \%$ \\
\hline $\begin{array}{l}\text { - ут. ч. повний debranching, операція } \\
\text { Whеаt та СЕТ }\end{array}$ & 1 & $2,4 \%$ \\
\hline - ут. ч. повний debranching та СЕТ & 1 & $2,4 \%$ \\
\hline Усього & $\mathbf{4 1}$ & $\mathbf{1 0 0 , 0 \%}$
\end{tabular}

аорти (debranching) залежно від кількості реімплантованих у висхідну аорту судин поділяється на частковий debranching - 3 відсіченням і реімплантацією однієї судини; субтотальний - 3 реімплантацією двох судин; повний - з відсіченням і реімплантацією всіх гілок дуги аорти [7]. Пацієнтам з ураженням висхідної аорти одночасно виконувалося усунення ураження висхідної аорти (повний debranching з супракоронарним протезуванням висхідної аорти, повний debranching з операцією Wheat та Conventional Elephant Trunk (CET), повний debranching з CET). Крім того, хворому з посткоарктаційною аневризмою низхідної аорти та супутнім аортальним стенозом через два тижні після гібридного лікування низхідної аорти була виконана операція Robicsek.

Результати. Контроль стану пацієнтів у віддаленому періоді виконувався з інтервалом 3 та 6 місяців після операції. Через 3 місяці виконувалось УЗДдослідження, а в разі наявності скарг - КТ-аортографія 3 контрастуванням; через 6 місяців усім хворим виконувалась КТ-аортографія.

Всі пацієнти успішно перенесли операцію. Через три місяці після гібридного лікування померла одна пацієнтка. Цій хворій із розшаруванням аорти типу В у гострий період успішно виконали хірургічне втручання. Проте після виписки зі стаціонару в неї виникло ретроградне розшарування аорти, що і стало причиною смерті.

Таким чином, смертність у тримісячний термін становила 2,4\%. На етапі спостереження від трьох до шести місяців після лікування летальних випадків не було.

В 11 пацієнтів під час процедури спостерігався endoleak I типу. У семи пацієнтів endoleak був незначним; у чотирьох - суттєвим, тому в останньому випадку хворим виконувалася рентген-ендоваскулярна дилатація (РЕД) проксимальної частини стента. Через шість місяців на контрольній КТ-аортограмі endoleak I типу спостерігався в одного пацієнта, пацієнту було виконано ендоваскулярне закриття джерела endoleak спіраллю Nit-occlud le VSD. 
У 8 випадках після встановлення стент-графта спостерігався endoleak II типу, з них у двох випадках він був мінімальним; у шести випадках джерело endoleak (ліва підключична артерія; в одному випадку - плечоголовний стовбур) було закрите оклюдером. На контрольних КТ-аортограмах через три та шість місяців не було виявлено жодного endoleak II типу.

В одного пацієнта 3 хронічним розшаруванням аорти типу В після часткового debranching під час ангіографії спостерігалося недостатнє заповнення лівої ниркової артерії з фальшивого каналу, а видимих фенестрацій не було виявлено. 3 метою збереження кровопостачання лівої нирки після імплантації стент-графта аорти була виконана перфорація інтими між істинним та фальшивим каналами на рівні вічок ниркових артерій та РЕД фенестрації фальшивого каналу. Після процедури ліва ниркова артерія добре контрастується через фальшивий канал з істинного.

У хворого з хронічною розшаровуючою аневризмою аорти типу B TEVAR було виконано через два місяці після субтотального debranching через технічні особливості (тривале очікування стент-графта на замовлення). При виконанні TEVAR було виявлено тромбоз каротидно-підключичного анастомозу. У цей же день після ендоваскулярного втручання пацієнту було повторно виконано каротидно-підключичне шунтування.

В одному випадку після імплантації стент-графт зайняв неправильну позицію по внутрішній кривині дуги аорти 3 конфігурацією «дзьоб птаха»; після підтягування стент-графта петлею з правої підключичної артерії положення стента задовільне.

У пацієнта з хронічним розшаруванням аорти типу В після двобічного каротидно-підключичного шунтування на першому етапі лікування після виконання TEVAR та закриття гирл підключичних артерій оклюдерами сталося перекриття гирла лівої хребетної артерії, а під час видалення оклюдера - розшарування лівої підключичної артерії, яке, проте, не потребувало втручання. У цього ж хворого спостерігали осиплість голосу внаслідок травми зворотного гортанного нерва.

Ускладнення лікування відображено в табл. 3.

\section{Таблиця 3}

Структура ускладнень

\begin{tabular}{lc} 
Ускладнення & Кількість, $\mathbf{n ~ ( \% ) ~}$ \\
\hline Endoleak I типу у віддаленому періоді & $1(2,4 \%)$ \\
\hline $\begin{array}{l}\text { Тромбоз каротидно-підключичного анасто- } \\
\text { мозу }\end{array}$ & $1(2,4 \%)$ \\
\hline Розшарування лівої підключичної артерії & $1(2,4 \%)$ \\
\hline Травма зворотного гортанного нерва & $1(2,4 \%)$ \\
\hline Exitus letalis до 3 місяців після операції & $1(2,4 \%)$ \\
\hline Bcьoro & $\mathbf{5 ( 1 2 , 2 \% )}$
\end{tabular}

Обговорення результатів. Відкрите хірургічне лікування аневризм дуги та низхідної аорти в умовах штучного кровообігу та перетискання аорти є вкрай важкою операцією з високим рівнем смертності та ускладнень. За даними літератури, летальність при відкритих операціях з приводу розшарування аорти типу В становить від 11 до 32\%; такі грізні ускладнення, як гостре порушення мозкового кровообігу, ішемія спинного мозку, післяопераційна ниркова недостатність, мають частоту відповідно 5,6\% , 4,9\% та 11,9\% [8, 9]. У НІССХ до появи ендоваскулярного лікування хворим із патологією низхідної аорти, що безпосередньо не загрожувала життю (ізольована аневризма низхідної аорти, розшарування аорти типу В, не ускладнене розривом або мальперфузією внутрішніх органів, пенетруюча виразка аорти), було показане виключно медикаментозне лікування у зв'язку з украй високим ризиком оперативного лікування, високою летальністю та рівнем ускладнень.

Впровадження у практику ендоваскулярного методу відкрило нові можливості лікування цих пацієнтів. Водночас ізольоване ендоваскулярне лікування не може бути застосоване при ураженнях аорти, які знаходяться ближче ніж 2 см до судин дуги або залучають їх. Гібридне лікування з переключенням гілок дуги аорти відкритим методом з подальшим ендоваскулярним протезуванням низхідної аорти стент-графтом дозволило нівелювати цю проблему. Гібридний метод має низьку летальність і частоту ускладнень, добре переноситься хворими, значно скорочує час перебування в реанімації та в умовах стаціонару.

Оскільки гібридний метод лікування патології грудної аорти набув популярності порівняно недавно, на даний час все ще у процесі виконання знаходиться Кокранівський систематичний огляд порівняння результатів гібридного лікування і традиційного хірургічного лікування розшаровуючих аневризм аорти [10], але вже існує достатня кількість досліджень груп хворих, у тому числі досвід нашого закладу, що свідчать на користь гібридного лікування патології грудної аорти.

Варто також зазначити, що в низці випадків альтернативою гібридному методу лікування може стати використання фенестрованих стент-графтів (фабричних або фенестрованих під час операціï in vitro чи in situ): з 2017 року в НІССХ почали проводитися імплантації стент-графтів аорти з фенестраціями in vitro, які виконуємо на операційному столі безпосередньо перед імплантацією.

Висновки. Гібридні методики лікування захворювань грудної аорти є сучасною альтернативою традиційному хірургічному лікуванню цієї патології. Гібридний метод значно зменшує операційну травму і скорочує час операції, завдяки чому покращує післяопераційний перебіг. Саме це робить його мето- 
дом вибору при патології аорти, що супроводжується тяжкими супутніми захворюваннями, коли тривала операція під ендотрахеальним наркозом становить високий ризик для пацієнта, або при розшаровуючих аневризмах аорти з важкими ускладненнями (мальперфузія внутрішніх органів, гемоторакс). Якшо при плановому гібридному лікуванні відкритий етап передує ендоваскулярному, при ситуаціях, що загрожують життю пацієнта (розрив аорти з гемотораксом, гостре розшарування аорти з мальперфузією внутрішніх органів), доцільно негайно виконати ендопротезування низхідної аорти для стабілізації стану хворого та усунення безпосередньої загрози його життю, після чого провести переключення гілок дуги аорти. Також одномоментно з ендопротезуванням аорти можливо виконати дренування плевральної порожнини при гемотораксі. Без виконання переключення гілок дуги аорти є загроза інсульту при активізації хворого через обкрадання мозкового кровообігу, тому цей етап є необхідним. У разі гострого розшарування аорти типу В без ускладнень, що потребували б негайної корекції, оптимальним періодом для гібридного лікування патології є 2-3 місяці після виникнення розшарування, коли процес переходить у хронічну стадію.

\section{Література}

1. Самофиксирующийся синтетический протез для эндопротезирования сосудов / Володось Н. Л. [и др.] // Вестник хирургии. - 1986. - Т. 137, № 11. C. $123-124$.

2. Volodos N. L. The origin of TEVAR / Chiesa R., Melissano G., Setacci C. [et al.] // History of aortic surgery in the world. - Turin (Italy), 2015. - P. 2-10.
3. David A. Nation. TEVAR: Endovascular Repair of the Thoracic Aorta / Nation D. A., Wang G. J. // Semin Intervent Radiol. - 2015. - Vol. 32, № 3. - P. 265-271.

4. Thoracic Endovascular Aortic Repair (TEVAR) for the treatment of aortic diseases: a position statement from the European Association for Cardio-Thoracic Surgery (EACTS) and the European Society of Cardiology (ESC), in collaboration with the European Associationof Percutaneous Cardiovascular Interventions (EAPCI) / Grabenwцger M., Alfonso F., Bachet J. [et al.] // Eur Heart J. - 2012. - № 33. - P. 1558-1563.

5. Hybrid treatment of complex aortic arch disease with supraaortic debranching and endovascular stent graft repair / Antoniou G. A., El Sakka K., Hamady M. [et al.] // Eur J Vasc Endovasc Surg. - 2010. - Vol. 39, № 6. - P. 683-690.

6. 2014 ESC Guidelines on the diagnosis and treatment of aortic diseases / Erbel R., Aboyans V., Boileau C. [et al.] // Eur Heart J. - 2014. - Vol. 35, № 41. - P. 2873-2926.

7. Multicentre analysis of current strategies and outcomes in open aortic arch surgery: heterogeneity is still an issue / Urbanski P. P., Luehr M., Di Bartolomeo R. [et al.] // Eur J Cardiothorac Surg. - 2016. - № 50. - P. 249-255.

8. Open surgical repair for chronic type B aortic dissection: a systematic review / Tian D. H., De Silva R. P., Wang T. [et al.] // Ann Cardiothorac Surg. - 2014. - Vol. 3, № 4. P. 340-350.

9. The International Registry of Acute Aortic Dissection (IRAD): new insights into an old disease / Hagan P. G., Nienaber C. A., Isselbacher E. M. [et al.] // JAMA. 2000. - № 283. - P. 897-903.

10. Hybrid repair versus conventional open repair for thoracic aortic arch aneurysms (Protocol) [Електронний pecypc] / Elhelali A., Hynes N., Devane D. [et al.] // Cochrane Database of Systematic Reviews. - 2018. - № 1. - Peжим доступу до журн. : http://onlinelibrary.wiley.com/ doi/10.1002/14651858.CD012923/full.

\title{
Hybrid treatment methods for diseases of thoracic aorta
}

\author{
Mazur O. A. Jr., Ditkivsky I. O., Cherpak B. V., Kravchenko V. I.
}

National M. M. Amosov Institute of Cardiovascular Surgery

National Academy of Medical Sciences of Ukraine (Kyiv)

\begin{abstract}
Hybrid treatment of aortic pathology doesn't have the drawbacks of conventional surgical methods. At the same time it has much wider possibilities of application than the endovascular method, which has significant anatomical limitations.

In years 2014-2017 41 patients of Amosov National Institute of Cardiovascular Surgery with thoracic aortic pathology underwent hybrid treatment (open surgery on aortic arch branches and TEVAR). $(n=19)$ patients had descending aortic aneurysm without dissection or rupture; $(n=19)$ patients had aortic dissection $(n=4-$ acute, $n=2-$ subacute, $n=13-$ chronic), two patients had aortic aneurysm rupture and in one case the patient had PAU.

Patients scheduled for elective surgery or those not in critical conditions had debranching of aortic arch at the first stage and TEVAR at the second stage. If they had life-threatening conditions (such as aortic rupture, visceral malperfusion), they underwent TEVAR immediately and after their condition improved, open surgery stage was conducted.

Patient check-ups took place three and six months after hybrid treatment. Mortality rate was $2,4 \%$, which is much lower than mortality rates for open surgical repair of descending aorta. Among the complications there were type I endoleak at a remote period; carotid-subclavian shunt thrombosis, left subclavian artery dissection and trauma of $\mathrm{n}$. laryngeus recurrens (one case each). Three-month and six-month results of the treatment were good.
\end{abstract}

Key words: aortic aneurysm, aortic dissection, hybrid treatment, TEVAR, debranching, carotid-subclavian bypass. 


\title{
Гибридные методики в лечении патологии грудной аорты
}

\author{
Мазур А. А., Дитковский И. А., Черпак Б. В., Кравченко В.И. \\ ГУ «Национальный институт сердечно-сосудистой хирургии имени Н. М. Амосова НАМН» (Киев)
}

Гибридный метод лечения патологии грудной аорты лишен недостатков традиционных «открытых» хирургических методов лечения и в то же время имеет более широкие возможности применения, чем эндоваскулярный метод, характеризующийся существенными анатомическими ограничениями.

С 2014 по 2017 г. в ГУ «Национальный институт сердечно-сосудистой хирургии имени Н. М. Амосова НАМН» 41 пациент с патологией грудной аорты получил гибридное лечение (открытая операция на сосудах дуги аорты и эндопротезирование нисходящей аорты). У $(\mathrm{n}=19)$ пациентов была аневризма нисходящей аорты без расслоения или разрыва; у (n=19) больных наблюдалась расслаивающая аневризма аорты $(\mathrm{n}=4$ - острая, $\mathrm{n}=2$ - подострая, n=13 - хроническая), у двух больных был разрыв аорты без расслоения, и в одном случае наблюдалась пенетрирующая язва аорты.

Пациентам, поступающим в плановом порядке или без состояний, угрожающих жизни, проводилось переключение сосудов дуги аорты (дебранчинг) на первом этапе и эндопротезирование нисходящей аорты на втором этапе. Если существовала непосредственная угроза жизни пациента (разрыв аорты, мальперфузия внутренних органов), сначала проводилось эндопротезирование аорты стент-графтом, потом, после стабилизации состояния пациента, выполнялся открытый этап лечения.

Контроль состояния пациентов в отдаленном периоде проводился на третьем и шестом месяцах после гибридного лечения. Летальность составила $2,4 \%$, что значительно меньше летальности при открытом протезировании нисходящей аорты. Среди осложнений были эндолик I типа в отдаленном периоде; тромбоз каротидно-подключичного анастомоза, расслоение левой подключичной артерии и травма возвратного гортанного нерва (по одному случаю). Результаты лечения через три и шесть месяцев хорошие.

Ключевые слова: аневризма аорты, расслоение аорты, гибридное лечение, эндоваскулярное протезирование грудной aорты, TEVAR, дебранчинг, каротидно-подключичное шунтирование. 